\title{
Growth hormone binding protein and acid labile subunit levels in the assessment of acromegaly treatment
}

\author{
Marinella Tzanela, Marieta Christoforaki, Lida Papastathopoulou, Dimitra Vassiliadi, \\ Effie Botoula, Panagiotis Trivizas, Nikos C. Thalassinos
}

Department of Endocrinology, Diabetes and Metabolism, Evangelismos Hospital, Athens, Greece

\begin{abstract}
OBJECTIVE: Post-treatment monitoring of acromegalic patients is a matter of controversy, as discrepancies between GH and IGF-I levels have been reported. The aim of our study was to evaluate the role of acid-labile subunit (ALS), a component of the $150 \mathrm{kD}$ IGF-I/IGFBP-3/ALS complex, and the growth hormone binding protein (GHBP) in the follow-up of patients with acromegaly after therapeutic intervention. DESIGN: Forty-one patients with acromegaly, 10 at the time of diagnosis and 31 post therapeutic intervention, were studied. Patients were evaluated by the determination of baseline (fasting) IGF-I, ALS and GHBP and of glucose and GH during OGTT. RESULTS: Significantly lower ALS and higher GHBP levels were detected in successfully treated acromegalics compared to patients before treatment $(34.1 \pm 1.6 \mathrm{vs} .52 .8 \pm 2$ $\mathrm{mg} / \mathrm{L}$ and $0.9 \pm 0.08$ vs $0.4 \pm 0.1 \mu \mathrm{g} / \mathrm{L}$, respectively $P<0.05)$. Furthermore, no difference was noted in ALS and GHBP values between patients successfully treated with either somatostatin analogues or another type of treatment. CONCLUSIONS: a) Successfully treated acromegalic patients demonstrate lower ALS and higher GHBP levels than patients before treatment, and b) somatostatin analogue treatment does not have a direct effect on GHBP and ALS concentration in acromegaly. Studies in larger groups of patients are needed to disclose whether these alterations will be useful in the post-treatment assessment of acromegalic patients.
\end{abstract}

Key words: Acromegaly, Acid labile subunit, Growth hormone binding protein

\section{INTRODUCTION}

Acromegaly is a rare disease which leads to high rates of morbidity and mortality ${ }^{1}$. Epidemiological studies have shown that adequate control of acrome-

Address correspondence and requests for reprints to: M. Tzanela, MD, Department of Endocrinology, Diabetes and Metabolism, Evangelismos Hospital, 45-47 Ipsilantous St., 10676 Athens, Greece, Tel: 210-7201825, 2107201826, Fax: 210-7249746, e-mail: mtzanel@med.uoa.gr Received 06-06-05, Revised 06-07-05, Accepted 10-07-05 galy restores mortality rates to those of the general population ${ }^{2,3}$. GH nadir levels $<1 \mu \mathrm{g} / \mathrm{L}$ during an oral glucose tolerance test (OGTT) and normal for age and sex IGF-I levels are the current criteria for acromegaly control ${ }^{4,5}$. However, it has been demonstrated that $15-30 \%$ of acromegalics with normal IGF-I values fail to normalize GH levels and vice versa $^{6}$. Diurnal variation of $\mathrm{GH}$ secretion ${ }^{7}$, problems with reproducibility ${ }^{8}$ and sensitivity of GH assays ${ }^{9}$, methodological problems with IGF-I measurements 
due to binding proteins ${ }^{10}$ and the direct inhibitory effect of somatostatin and its analogues on IGF-I production $^{11}$ are factors that account for these discrepancies and create diagnostic uncertainties in the follow-up of acromegalic patients. When GH receptor antagonists are used for the treatment of acromegaly $^{12,13}$, IGF-I levels are the only tool available to evaluate disease activity; thus, the need to assess the validity of other markers for this purpose is imperative.

Acid-labile subunit (ALS) is a component of the $150 \mathrm{kD}$ IGF-I/IGFBP-3/ALS complex, essential for ensuring constant plasma IGF-I levels ${ }^{14}$. It has been shown that ALS is independent of mechanisms that influence IGF-I and IGFBP-3 secretion ${ }^{15}$ and is less age-dependent than IGF-I and IGFBP- $3^{16}$. Furthermore, unlike IGF-I and IGFBP-3, ALS is not affected by impaired anterior pituitary function ${ }^{17}$.

The high affinity Growth Hormone Binding Protein (GHBP) is the soluble extracellular portion of the $\mathrm{GH}$ receptor, derived by proteolytic cleavage ${ }^{18}$. This protein binds $40-50 \%$ of circulating $\mathrm{GH}$ and seems to protect $\mathrm{GH}$ from elimination and degradation, thus regulating $\mathrm{GH}$ action ${ }^{19}$. It has been shown that GHBP levels reflect GH tissue receptor status $^{18}$. The secretion of GHBP is GH dependent and, as their circulating concentration is relatively stable during the day ${ }^{20}$, they provide an estimate of the integrated GH secretion.

In acromegaly, decreased GHBP ${ }^{20-22}$ and increased $\mathrm{ALS}^{16,17,23}$ levels have been reported. Thus, these two parameters may offer a potentially useful tool in the assessment of disease activity in acromegaly after therapeutic intervention.

The aim of our study was to evaluate the effect of acromegaly treatment on ALS and GHBP levels and their differential role in assessing treatment efficacy of patients with acromegaly. We also examined the differential effect of somatostatin analogues and other treatment modalities on ALS or GHBP levels in acromegalic patients.

\section{PATIENTS AND METHODS}

A total of 41 patients with acromegaly were included in the present retrospective, cross-sectional study. The diagnosis of acromegaly was made on the basis of signs and symptoms of the disease, elevated random GH levels ( $>2.5 \mu \mathrm{g} / \mathrm{L})$, not adequately suppressed (below $1 \mu \mathrm{g} / \mathrm{L}$ ) by an oral glucose load, (OCTT) elevated IGF-I levels and radiological detection of a pituitary adenoma ${ }^{4}$.

The study group included 10 patients evaluated at the time of diagnosis and before any therapeutic intervention (pretreatment group), and 31 patients evaluated after therapeutic intervention. Fourteen out of the 31 patients had normal IGF-I values for age and sex and GH levels $<1 \mu \mathrm{g} / \mathrm{L}$ during OGTT post treatment, and were considered in remission (successfully treated group), whereas 17 patients failed to meet the above criteria ${ }^{4,5}$ and were designated as an unsuccessfully treated group. Of the 23 acromegalics who achieved normal IGF-I for age and sex post treatment, 9 patients failed to meet all the current consensus criteria for acromegaly control, as they demonstrated inadequate GH suppression $(\mathrm{GH}>1 \mu \mathrm{g} / \mathrm{L})$ during an OGTT. Details on anthropometric, biochemical and hormonal characteristics of the 3 groups of patients are depicted in Table 1 . The study was approved by the local ethical committee and consent was obtained from the patients involved.

The 31 patients studied post-treatment had been submitted to different therapeutics modalities (transsphenoidal surgery, radiotherapy and somatostatin analogue administration) according to standard treatment algorithms ${ }^{12}$ and were evaluated at least 3 months after surgery or initiation of somatostatin analogue treatment and 3 years after radiation treatment. Slow-release long-acting somatostatin analogues were used (Sandostatin LAR 20 or 30 $\mathrm{mg}$ im every 4 weeks, Novartis, and Somatulin $30 \mathrm{mg}$ every 2 weeks, Ipsen, France).

All patients were ambulatory. Patients with pituitary hormones deficiencies were on standard replacement treatment. GH levels were measured under baseline conditions and the mean $\mathrm{GH}$ value of at least two samples were recorded. OGTT was performed as follows: After an overnight fast, a blood sample was drawn between 08:30 and 09:00 for baseline (fasting) determination of glucose, $\mathrm{GH}$, IGF-I, ALS and GHBP and at 30, 60, 90 and 120 
Table 1. Clinical characteristics and hormonal data of the 3 groups of patients with acromegaly

\begin{tabular}{lccc}
\hline & $\begin{array}{c}\text { Before } \\
\text { treatment }\end{array}$ & $\begin{array}{c}\text { Successfully } \\
\text { treated }\end{array}$ & $\begin{array}{c}\text { Unsuccessfully } \\
\text { treated }\end{array}$ \\
\hline $\mathrm{n}$ & 10 & 14 & 17 \\
Age (years) & $52.9 \pm 4$ & $48.1 \pm 3.8$ & $51.9 \pm 2.8$ \\
$\mathrm{M} / \mathrm{F}$ & $2 / 8$ & $5 / 9$ & $8 / 9$ \\
$\mathrm{Micro} /$ macro & $4 / 6$ & $5 / 9$ & $7 / 10$ \\
$\mathrm{BMI}$ & $27.4 \pm 1$ & $26.4 \pm 0.8$ & $27.8 \pm 0.85$ \\
$\mathrm{~W} / \mathrm{H}$ & $0.86 \pm 0.03$ & $0.83 \pm 0.02$ & $0.87 \pm 0.02$ \\
$\mathrm{Mean} \mathrm{GH}(\mu \mathrm{g} / \mathrm{L})$ & $32.4 \pm 14.6$ & $1.04 \pm 0.2^{\mathrm{a}}$ & $8.86 \pm 3.59^{\mathrm{b}}$ \\
$\mathrm{GHn}(\mu \mathrm{g} / \mathrm{L})$ & $21.8 \pm 12.7$ & $0.5 \pm 0.06^{\mathrm{a}}$ & $4.9 \pm 2.2^{\mathrm{b}}$ \\
$\mathrm{IGF}-\mathrm{I}(\mu \mathrm{g} / \mathrm{L})$ & $545 \pm 58.9$ & $179.9 \pm 16.3^{\mathrm{a}}$ & $321.7 \pm 42.4^{\mathrm{b}}$ \\
\hline
\end{tabular}

\section{Treatment}

\begin{tabular}{llll}
\hline TSS & - & 5 & - \\
TSS+XR & - & 4 & 2 \\
TSS+SMS & - & 2 & 9 \\
SMS & - & 3 & 6 \\
\hline
\end{tabular}

$\mathrm{M} / \mathrm{F}=$ male to female ratio, micro/macro $=$ microadenomas to macro adenomas ratio, $\mathrm{BMI}=$ body mass index $\left(\right.$ weight $(\mathrm{kg}) /$ height $\left.(\mathrm{m})^{2}\right)$, $\mathrm{GHn}=\mathrm{GH}$ nadir during OGTT, TSS $=$ transsphenoidal surgery, $\mathrm{XR}=$ radiotherapy, $\mathrm{SMS}=$ somatostatin analogue,

$\mathrm{W} / \mathrm{H}=$ waist to hip ratio

a: statistically significant difference compared to values of patients before treatment

b: statistically significant difference compared to values of successfully treated patients

min after glucose load ( $75 \mathrm{~g}$ of dextrose) for the determination of glucose and $\mathrm{GH}$.

\section{Hormone assays}

Samples were collected and centrifuged and serum was stored in aliquots at $-20 \mathrm{C}^{\circ}$ until assayed. All samples were processed in duplicate.

Serum GH concentrations were determined by a commercially available immunoradiometric assay (IRMA) kit (CIS bio international, Gif-sur-Yvette, France). The minimum detection limit was $0.04 \mu \mathrm{g} /$ L. The intra-assay coefficient of variation was $2.4 \%$ and $2.8 \%$ at a concentration of $3.46 \mu \mathrm{g} / \mathrm{L}$ and $17 \mu \mathrm{g} /$ L, respectively. Serum IGF-I was measured by a commercially available immunoradiometric assay (IRMA) kit (Nichols Institute, San Juan Capistrano, CA, USA). This assay uses large excess of IGFII to block IGFBPs and has been validated against the Nichols acid-ethanol extraction RIA. The intraassay coefficient of variation was $4.6 \%, 3.3 \%$ and $4.1 \%$ at a concentration of $60.1 \mu \mathrm{g} / \mathrm{L}, 312 \mu \mathrm{g} / \mathrm{L}$ and $594.3 \mu \mathrm{g} / \mathrm{L}$, respectively.

GHBP levels were determined by enzyme-linked immunosorbent assay (ELISA) kit (Diagnostic System Laboratories, Inc., Webster, TX, USA). The intra-assay coefficient of variation was $5.4 \%, 1.8 \%$ and $5.1 \%$ at a concentration of $0.82 \mu \mathrm{g} / \mathrm{L}, 3.83 \mu \mathrm{g} / \mathrm{L}$ and $10.4 \mu \mathrm{g} / \mathrm{L}$, respectively.

ALS levels were determined by a specific twosite sandwich enzyme-linked immunosorbent assay (ELISA) kit (Diagnostic System Laboratories, Inc Webster, TX, USA). All samples were pretreated in order to dissociate the complex and enhance ALS immunoreactivity. The detection limit was $0.07 \mathrm{mg} /$ L. The intra-assay coefficient of variation was $6.1 \%$ and $3.8 \%$ at a concentration of $1.65 \mathrm{mg} / \mathrm{L}$ and 29.17 $\mathrm{mg} / \mathrm{L}$, respectively.

\section{Statistical analysis}

Data analyses were performed with a SAS statistical program. Statistical analysis to identify differences between groups of patients was performed with one way ANOVA followed by Student-Newman-Keuls test for comparisons between means or one way ANOVA on the ranks followed by Dunn's test for comparisons between means when data distribution was not normal. Spearman's correlation coefficient was used to evaluate the relationship between values. Data are expressed as mean \pm SE. The level of significance was set at 0.05 for all statistical tests.

\section{RESULTS}

\section{ALS and GHBP levels}

Individual ALS levels of all patients in the 3 groups are shown in Figure 1. Mean ALS levels were significantly $(\mathrm{P}<0.05)$ lower in the 14 successfully treated acromegalic patients, $(34.1 \pm 1.6 \mathrm{mg} / \mathrm{L})$ compared to the 10 patients of the pretreatment group $(52.8 \pm 2 \mathrm{mg} / \mathrm{L})$. Also, significantly $(\mathrm{P}<0.05)$ lower ALS levels were noted in the 14 successfully treated patients $(34.1 \pm 1.6 \mathrm{mg} / \mathrm{L})$ compared to the $17 \mathrm{un}$ successfully treated patients $(42.4 \pm 2.2 \mathrm{mg} / \mathrm{L})$. 


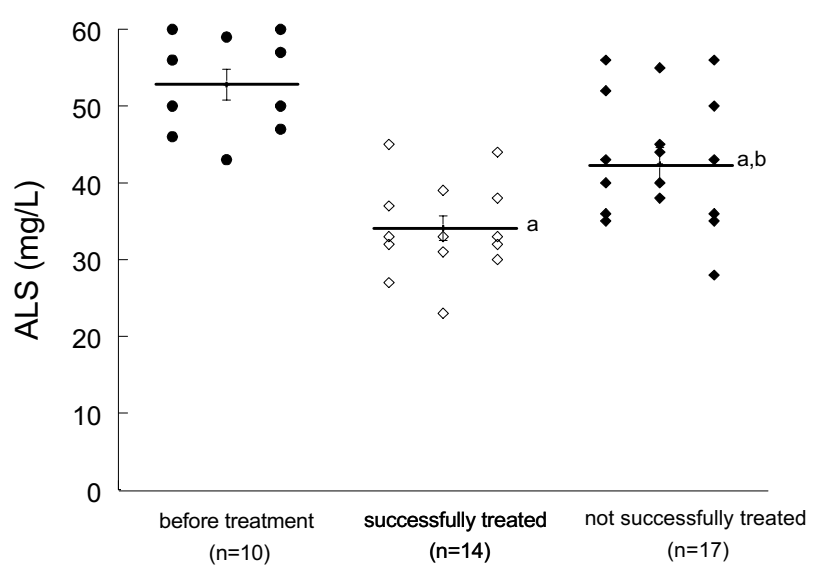

Figure 1. Individual Acid-labile subunit (ALS) levels in patients with acromegaly before treatment $(\bullet, \mathrm{n}=10)$, and in successfully $(\diamond, n=14)$ or not successfully treated $(\diamond, n=17)$ patients. Horizontal bars indicate mean value \pm SE for the respective group.

a: denotes statistically significant difference compared to patients before treatment $(\mathrm{P}<0.05)$

b: denotes statistical significant difference compared to successfully treated patients, $(\mathrm{P}<0.05)$.

As shown in Figure 2, mean GHBP levels were significantly $(\mathrm{P}<0.05)$ higher in successfully treated acromegalics $(0.9 \pm 0.08 \mu \mathrm{g} / \mathrm{L})$, compared to patients before treatment $(0.4 \pm 0.1 \mu \mathrm{g} / \mathrm{L})$, and to unsuccessfully treated patients $(0.6 \pm 0.1 \mu \mathrm{g} / \mathrm{L}, \mathrm{P}$ $<0.05)$. No difference in GHBP levels was noted between patients before treatment and unsuccessfully treated acromegalic patients.

In acromegalic patients post treatment, a statistically significant positive correlation was disclosed between ALS, GH $(\mathrm{R}=0.52, \mathrm{P}=0.002)$, IGF-I $(\mathrm{R}=0.68, \mathrm{P}=0.0001)$ and $\mathrm{GH}$ nadir values during an OGTT $(\mathrm{R}=0.48, \mathrm{P}=0.02)$, while a significant negative correlation was disclosed between GHBP, $\mathrm{GH}(\mathrm{R}=-0.38, \mathrm{P}=0.04)$, and IGF-I levels $(\mathrm{R}=-0.62$, $\mathrm{P}=0.0001)$. No correlation was found between either ALS or GHBP and age, body mass index (BMI) or Waist to Hip ratio.

\section{Somatostatin effect on ALS and GHBP levels}

To examine whether the alterations of ALS and GHBP levels after therapeutic interventions as described above were influenced by somatostatin administration, successfully treated acromegalic patients on slow-released long-acting somatostatin

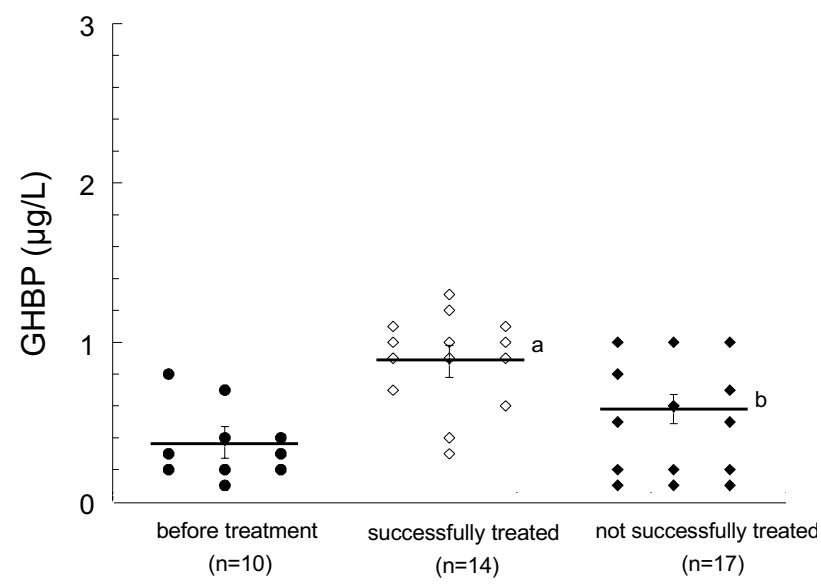

Figure 2. Individual growth hormone binding protein (GHBP) levels in patients with acromegaly before treatment $(\bullet, \mathrm{n}=10)$, and in successfully $(\diamond, n=14)$ or not successfully treated $(\bullet$, $\mathrm{n}=17$ ) patients. Horizontal bars indicate mean value $\pm \mathrm{SE}$ for the respective group.

a: denotes statistically significant difference compared to patients before treatment $(\mathrm{P}<0.05)$

b: denotes statistically significant difference compared to successfully treated patients, $(\mathrm{P}<0.05)$.

analogues $(\mathrm{n}=5)$ were compared with acromegalics successfully treated by transphenoidal surgery or pituitary irradiation $(n=9)$. No differences in ALS or GHBP levels were disclosed between these 2 groups (Table 2). As expected, statistically significant differences $(\mathrm{P}<0.05)$ in ALS and GHBP values were found between patients successfully and unsuccessfully treated with somatostatin analogues $(31.6 \pm 1.3 \mathrm{vs} 43.2 \pm 2.3 \mathrm{mg} / \mathrm{L}$ for ALS, and $1.08 \pm 0.04$ vs $0.5 \pm 0.11 \mu \mathrm{g} / \mathrm{L}$ for GHBP, Table 2 ).

\section{DISCUSSION}

In most studies on mortality and morbidity related to acromegaly, random GH and IGF-I levels ${ }^{2,3}$ have been used as indices of treatment efficacy. Recent studies, however, provide evidence for the necessity of using GH nadir values during an OGTT in the long-term follow-up of acromegalic patients post therapy. Thus, nadir GH levels $<0.3 \mu \mathrm{g} / \mathrm{L}$ are considered a good predictor of long-term remission of the disease $\mathrm{e}^{9,24,25}$. The baseline IGF-I and GH values during OGTT are the two parameters used in the assessment of disease activity in acromegaly after treatment with either transphenoidal surgery, 
Table 2. Clinical characteristics and hormonal data of patients with acromegaly after treatment

\begin{tabular}{lccc}
\hline & $\begin{array}{c}\text { Unsuccessfully } \\
\text { treated } \\
(+ \text { SMS })\end{array}$ & $\begin{array}{c}\text { Successfully } \\
\text { treated } \\
(+ \text { SMS })\end{array}$ & $\begin{array}{c}\text { Successfully } \\
\text { treated } \\
(-S M S)\end{array}$ \\
\hline $\mathrm{n}$ & 15 & 5 & 9 \\
Age $($ years $)$ & $51.3 \pm 2.9$ & $53.7 \pm 7.4$ & $45.6 \pm 4.5$ \\
Mean GH $(\mu \mathrm{g} / \mathrm{L})$ & $9.8 \pm 4$ & $1.1 \pm 0.2^{\mathrm{a}}$ & $0.9 \pm 0.3^{\mathrm{a}}$ \\
$\mathrm{GHn}(\mu \mathrm{g} / \mathrm{L})$ & $5.4 \pm 2.5$ & $0.64 \pm 0.1^{\mathrm{a}}$ & $0.4 \pm 0.05^{\mathrm{a}}$ \\
$\mathrm{IGF}-\mathrm{I}(\mu \mathrm{g} / \mathrm{L})$ & $340.6 \pm 45.8$ & $174.4 \pm 21.3^{\mathrm{a}}$ & $183 \pm 23.4^{\mathrm{a}}$ \\
$\mathrm{ALS}(\mathrm{mg} / \mathrm{L})$ & $43.2 \pm 2.3$ & $31.6 \pm 1.3^{\mathrm{a}}$ & $35.5 \pm 2.3^{\mathrm{a}}$ \\
$\mathrm{GHBP}(\mu \mathrm{g} / \mathrm{L})$ & $0.5 \pm 0.11$ & $1.08 \pm 0.04^{\mathrm{a}}$ & $0.9 \pm 0.1^{\mathrm{a}}$ \\
\hline
\end{tabular}

+ SMS acromegalic patients on slow-release long-acting somatostatin analogues treatment

-SMS = acromegalic patients who never received slow-release long-acting somatostatin analogues treatment, $\mathrm{GHn}=\mathrm{GH}$ nadir during OGTT

a: statistically significant difference compared to values of patients unsuccessfully treated with SMS, P <0.05

radiotherapy or somatostatin analogue administration $^{26-28}$. As plasma IGF-I levels and GH suppressibility to glucose represent different facets of the disease (i.e. overall GH hypersecretion and $\mathrm{GH}$ secretory dysregulation, respectively $)^{29}$, discrepancies between GH and IGF-I measurements are not uncommon ${ }^{6}$, creating diagnostic problems in the follow-up of acromegalic patients. In the present study we analysed data derived from acromegalic patients irrespective of treatment modality, as the abovementioned criteria for post treatment disease activity assessment refer to acromegalics submitted to any kind of treatment (surgery, radiotherapy and/or somatostatin analogue). We found that 9 patients, who failed to suppress GH levels, exhibited normal IGFI levels, indicating low specificity of IGF-I to accurately identify disease persistence according to the currently accepted criteria ${ }^{4,5}$. Such findings will lead to diagnostic uncertainties, especially in cases in which GH measurements cannot be used (i.e. in patients on $\mathrm{GH}$ receptor antagonist treatment) and evaluation of the effect of treatment is based only on IGF-I levels. Because of these uncertainties, we examined the potential use of ALS and GHBP as markers of disease activity in acromegaly after therapeutic intervention.
In agreement with other studies ${ }^{16,17,20-23}$, we found that successful treatment of acromegaly either by surgery, radiotherapy or somatostatin analogues leads to lower ALS and higher GHBP levels compared to patients before treatment. The use of ALS or GHBP in the assessment of acromegaly activity post treatment has been evaluated against the current criteria for disease control ${ }^{7,8}$ in only two reports $^{23,30}$. Hernadez et al. demonstrated that after treatment, GHBP levels became normal, particularly in those patients with undetectable GH levels during OGTT $^{30}$. More recently, it was shown that pathologically elevated IGF-I and/or ALS values indicated increased disease activity, irrespective of GH values $^{23}$. It must be underlined that overlap of both ALS and GHBP levels between successfully and unsuccessfully treated acromegalics was disclosed in our study and therefore these two parameters cannot be used independently to assess activity of acromegaly.

In the present study we also addressed the question of a direct effect of somatostatin analogues on ALS and GHBP synthesis and release, independent of GH levels. Such a direct inhibitory effect has recently been demonstrated on IGF-I production from hepatocytes ${ }^{11}$, as well as on other members of the IGF-I family such as IGFBP-1, both in vitro ${ }^{31}$ and in vivo ${ }^{32}$. Furthermore, a dose-dependent inhibitory effect of somatostatin on ALS secretion was found in hepatocyte culture ${ }^{15}$. In the present study we found that controlled acromegalics exhibited statistically similar alterations of ALS and GHBP, independently of treatment modality (transsphenoidal surgery or radiation or somatostatin analogue administration), providing evidence against an in vivo direct inhibitory effect of somatostatin upon ALS and GHBP secretion. However, the number of our patients being successfully treated with somatostatin analogues is too small to allow for definitive conclusions.

The results of the present study indicate that successful treatment of acromegaly reverses the GHBP and ALS alterations caused by the disease. Furthermore, treatment with slow-release long-lasting somatostatin analogues does not seem to have a direct effect on GHBP and ALS concentration in these 
patients. Larger studies will most likely provide stronger evidence as to whether these parameters are helpful in the post-treatment assessment of acromegaly.

\section{ACKNOWLEDGEMENTS}

The authors wish to thank Mrs Stavropoulou I. and Mrs Fildissi Chr. for their expert technical assistance. The help and support of the nurses and the staff of our department is also greatly appreciated.

\section{REFERENCES}

1. Colao A, Ferone D, Marzullo P, Lombardi G, 2004 Systemic complications of acromegaly: epidemiology, pathogenesis and management. Endocr Rev 25: 102152.

2. Bates AS, Van't Hoff W, Jones M, Clayton RN, 1993 An audit of outcome of treatment in acromegaly. Q J Med 86: 293-299.

3. Holdaway IM, Rajasoorya RC, Gamble GD, 2004 Factors Influencing Mortality in acromegaly. J Clin Endocrinol Metab 89: 667-674.

4. Guistina A, Barkan A, Casanueva F, et al, 2000 Criteria for cure of acromegaly: a consensus statement. J Clin Endocrinol Metab 85: 526-529.

5. Consensus statement, 2004 Biochemical assessment and long-term monitoring in patients with acromegaly: statement from a joint consensus conference of the growth hormone research society and the pituitary society. J Clin Endocrinol Metab 89: 3099-3102.

6. Shalet SM, 2004 Biochemical monitoring of disease activity after surgery for acromegaly. J Clin Endocrinol Metab 89: 492-494.

7. Pearcey SR, Toogood AA, Velduis JD, Thorner MO, Shalet SM, 2001 The relationship between 24 hrs growth hormone secretion and insulin-like growth factor I in patients with successfully treated acromegaly: impact of surgery or radiotherapy. J Clin Endocrinol Metabol 86: 259-266.

8. Granada ML, Sanmarti A, Lucas A, et al, 1990 Assaydependent results of immunoassayable spontaneous 24hour growth hormone secretion in short children. Acta Paediatr Scand Suppl 370: 63-70.

9. Costa ACF, Rossi A, Martinelli C, Machado HR, Moreira AC, 2002 Assessment of disease activity in treated acromegalic patients using a sensitive $\mathrm{GH}$ assay: Should we achieve strict normal GH levels for a biochemical cure? J Clin Endocrinol Metab 87: 31423147.

10. Rosenfield RC, Gargosky SH, 1996 Assays of insulinlike growth factors and their binding proteins: practi- calities and pitfalls. J Pediatr 128: S52-S57.

11. Murray RD, Kim K, Ren SG, Chelly M, Umehara Y, Melmed S, 2004 Central and peripheral actions of somatostatin on growth hormone-IGF-I axis. J Clin Invest 114: 349-356.

12. Melmed S, Casanueva F, Cavagnini F, et al, A 2002 Guidelines for acromegaly management J Clin Endocrinol Metab 87: 4054-4058.

13. Trainer PJ, Drake WM, Katznelson L, et al, 2000 Treatment of acromegaly with the growth hormone receptor antagonist pegvisomant. N Engl J Med 342: 11711177.

14. Baxter RC, Martin JL, Beniac VA, 1989 High molecular weight insulin-like growth factor binding protein complex. Purification and properties of the acid-labile subunit from human serum. J Biol Chem 264: 1184311848.

15. Barreca A, Voci A, Lee PD, et al, 1997 Effect of the somatostatin analog, octreotide, and of other hormones on the release of the acid-labile subunit (ALS) of the $150 \mathrm{kDa}$ complex by rat hepatocytes in primary culture. Eur J Endocrinol 137: 193-199.

16. Arosio M, Garrone S, Bruzzi P, Faglia G, Minuto F, Barreca A, 2001 Diagnostic value of the acid-labile subunit in acromegaly: Evaluation in comparison with Insulin-like growth factor (IGF) I, and IGF-Binding Protein -1, -2 and -3. J Clin Endocrinol Metab 86: 10911098.

17. Marzullo P, Di Somma C, Pratt K, et al, 2001 Usefulness of different biochemical markers of the insulinlike growth factor (IGF) familly in diagnosing growth hormone excess and deficiency in adults. J Clin Endocrinol Metab 86: 3001-3008.

18. Amit T, Youdim M, Hochberg Z, 2000 Does serum growth hormone binding protein reflect Human $\mathrm{GH}$ receptor function? J Clin Endocrinol Metab 85: 927932.

19. Tzanela M, Wagner C, Tannenbaum GST, 1997 Recombinant Human Growth Hormone-Binding Protein fails to enhance the in vivo bioactivity of human growth hormone in normal rats. Endocrinology 138: 5316-5324.

20. Kratzsch J, Blum W, Ventz M, Selisko T, Birkenmeyer G, Keller E, 1995 Growth Hormone-binding proteinrelated immunoreactivity in the serum of patients with acromegaly is regulated inversely by growth hormone concentration. Eur J Endocrinol 132: 306-312.

21. Amit T, Ish-Shalom S, Glaser B, Youdim M, Hochberg Z, 1992 Growth-Hormone-Binding protein in patients with acromegaly. Horm Res 37: 205-211.

22. Roelen CAM, Donker GH, Thijssen JHH, Koppeschaar HPF, Blankenstein MA, 1992 High affinity growth hormone binding protein in plasma of patients with acromegaly and the effect of octreotide treatment. Clin Endocrinol 1992 37: 373-378.

23. Minuto F, Resmini E, Boschetti M, et al, 2004 Assessment of disease activity in acromegaly by means of 
a single blood sample: comparison of the $120^{\text {th }}$ minute postglucose value with spontaneous $\mathrm{GH}$ secretion and with the IGF system. Clin Endocrinol 61: 138-144.

24. Freda PU, Nuruzzaman AT, Reyes CM, Sundeen RE, Post KD, 2004 Significance of "abnormal" nadir growth hormone levels after oral glucose in postoperative patients with acromegaly in remission with normal insulin-like growth factor-I levels. J Clin Endocrinol Metab 89: 495-500.

25. Biermasz N, Dekker F, Perreira AM, et al, 2004 Determinants of Survival in Treated Acromegaly in a Single Center: Predictive Value of Serial Insulin-Like Growth Factor I Measurements. J Clin Endocrinol Metab 89: 2789-2796.

26. Barkan AL, Biochemical markers of acromegaly: GH vs. IGF-I 2004. Growth Horm IGF Res14: S97-S100.

27. Ayuk J, Stewart SE, Stewart P, Sheppard MC, 2002 Long-term safety and efficacy of depot long-acting somatostatin analogs for the treatment of acromegaly. J Clini Endocrinol Metab 87: 4142-4146.
28. Freda P, 2002 Somatostatin analogs in acromegaly. J Clin Endocrinol Metab 87: 3013-3018.

29. AACE acromegaly task force, 2004 Medical guidelines for clinical practice for the diagnosis and treatment of acromegaly. Endocrine Practice 10: 213-225.

30. Hernadez I, Soderlung D, Espinosa de los Monteros AL, Raquel O, Zarate A, Mercado M, 1999 Differential effects of octreotide treatment and transphenoidal surgery on growth hormone-binding protein levels in patients with acromegaly. J Neurosurg 90: 647-650.

31. Ren SG, Ezzat S, Melmed S, Braunstein GD, 1992 Somatostatin analog induces insulin-like growth factor binding protein -1 (IGFBP-1) expression in human hepatoma cell. Endocrinology 131: 2479-2481.

32. Ezzat S, Ren SG, Braunstein GD, Melmed S, 1992 Octreotide stimulates Insulin-Like Growth-FactorBinding Protein-1: A potential pituitary-independent mechanism for drug action. J Clin Endocrinol Metab 75: 1459-1463. 